\title{
Rites for Dedicating Churches
}

Bruun, Mette Birkedal; Hamilton, Louis I.

Published in:

Understanding Medieval Liturgy

Publication date:

2015

Document version

Publisher's PDF, also known as Version of record

Citation for published version (APA):

Bruun, M. B., \& Hamilton, L. I. (2015). Rites for Dedicating Churches. In H. Gittos, \& S. Hamilton (Eds.), Understanding Medieval Liturgy: Essays in Interpretation (pp. 177-203). Ashgate. 


\title{
Chapter 8 \\ Rites for Dedicating Churches
}

\author{
Mette Birkedal Bruun and Louis I. Hamilton ${ }^{1}$
}

Although the precise origins of Christian rites for dedication are murky and the origin of Christian sacred space is itself debated, even the earliest Christians shared with Judaism a sense of terra sancta. ${ }^{2}$ In turn, the notion of Jerusalem as the holy land par excellence became canonical through the orthodox acceptance of the Book of Revelation as authentic. John's vision of the end of time culminates (in Revelation 21:12) in the re-establishment of Jerusalem: 'the holy city of Jerusalem coming down out of heaven from God.' ${ }^{3}$ After the conversion of Constantine, pilgrimage to Jerusalem rapidly became popular among Christians. ${ }^{4}$ It is also clear, that at least as early as Constantine, some churches were initiated by a distinct form of dedication rite. ${ }^{5}$ That is, almost as soon as Christianity was licit and took on a public role in Roman society, we have evidence both for some churches being dedicated in a distinct manner and for Jerusalem as a pilgrimage site. Dedication sermons, and with them much stronger evidence for the rite, soon followed. ${ }^{6}$ The notion that the space was distinct within the community and related to the Heavenly Jerusalem was commented on directly by Eusebius

1 Louis I. Hamilton wrote the introduction and the section on liturgical rites; Mette Birkedal Brunn that on sermons; the final reflections were jointly authored.

2 For a survey of the earliest evidence, see Francis E. Peters, Jerusalem: The Holy City in the Eyes of Chroniclers, Visitors, Pilgrims, and Prophets from the Days of Abraham to the Beginnings of Modern Times (Princeton: Princeton University Press, 1985).

3 See the brief overview of the development of the allegorical reading of scripture in early Christianity as it refers to the Temple in Ann R. Meyer, Medieval Allegory and the Building of the New Jerusalem (Cambridge: D.S. Brewer, 2003), 1-23.

4 E.D. Hunt, Holy Land Pilgrimage in the Later Roman Empire (Oxford: Oxford University Press, 1982).

5 Thaddeus S. Ziolkowski, The Consecration and Blessing of Churches: A Historical Synopsis and Commentary (Washington, DC: Catholic University of America Press, 1943).

6 For fifth-century Gaul, for example, Ian Wood has found ample evidence, 'The Audience of Architecture in Post-Roman Gaul', in The Anglo-Saxon Church: Papers on History, Architecture and Archaeology in Honour of Dr H.M. Taylor, ed. L.A.S. Butler and R.K. Morris (London: Council for British Archaeology, 1986), 74-79. 
of Caesarea (260-341 CE). ${ }^{7}$ The rapid emergence of practices of dedication may reflect an adaptation of preceding non-Christian practices and/or the existence of a Christian precedent lost to us. ${ }^{8}$

In the earliest centuries, an inaugural mass appears to have most commonly marked the dedication of the church. ${ }^{9}$ The deposition of relics into a new altar became normative from at least 787, when it was prescribed at the second Council of Nicaea. ${ }^{10} \mathrm{~A}$ rite for the deposition of relics in a new church appears in Roman ordines from about this time. ${ }^{11}$ There was never one rite for the dedication of churches in the Middle Ages, nor was the rite uniformly practised or enforced. Tracing changes in how it was practised (as opposed to how it was presented in liturgical texts or commentaries) is exceedingly difficult and much work remains to be done. ${ }^{12}$ The rite was unclear enough even to contemporaries that as late as the fifteenth century, a cleric complained that, 'Concerning the dedication or consecration of churches there is so much variety and various [customs] that, not only do they not agree in many points, but they often

7 Eusebius, Historia ecclesiastica, ed. Gustave Bardy, Sources chrétiennes, 31, 41, 55 and 73 (Paris: Cerf, 1952-60), Book X, cc. III-IV.

8 Louis I. Hamilton, A Sacred City: Consecrating Churches and Reforming Society in Eleventh-Century Italy (Manchester: Manchester University Press, 2010), 14. For an effort to further trace the origins of the rite, see Brian V. Repsher, 'The Abecedarium: Catechetical Symbolism in the Rite of Church Dedication', Mediaevalia 24 (2003): 1-18. See also Louis I. Hamilton, 'Les dangers du rituel dans l'Italie du XIe siècle: entre textes liturgiques et témoignages historiques', in Mises en scène et mémoires de la consécration d'église dans l'occident médiéval, ed. Didier Méhu (Turnhout: Brepols, 2008), 159-88.

9 Ziolkowski, Consecration and Blessing of Churches, 14-15.

10 Ziolkowski, Consecration and Blessing of Churches, 14-15.

11 OR, vol. 4, 336.

12 See Hamilton, Sacred City, 14. Physical evidence will prove essential in any effort to capture the earliest Christian notions of space. See, for example, the recent discoveries at Megiddo, described by Yotam Tepper and Leah Di Segni, $A$ Christian Prayer Hall of the Third Century CE at Kefar 'Othnay (Legio): Excavations at the Megiddo Prison 2005 (Jerusalem: Israel Antiquities Authority, 2006). The floor mosaics discovered certainly suggest a space set apart and marked for worship. Dominique Iogna-Prat and Collins both emphasize Paul's notion of the individual Christian as the temple: Dominique Iogna-Prat, La maison dieu: une histoire monumentale de l'église au moyen âge (v. 800-v. 1200) (Paris: Editions du Seuil, 2006), 30-33; Patrick Collins, The Carolingian Debate over Sacred Space (New York: Palgrave Macmillan, 2012), 7-8. Collins notes the wide range of views on sacred space in the first centuries of Christianity. It should be noted that Paul and the earliest Christians continued to worship at the Temple in Jerusalem, as at Acts 2:46 and 21:26. I am not convinced that Paul's notion of the body as Temple was intended as an assault on sacred space per se, or that early Christians understood it as such. See also Jennifer Harris, 'The Body as Temple in the High Middle Ages', in Sacrifice in Religious Experience, ed. Albert I. Baumgarten (Leiden: Brill, 2002), 233-56. 
contradict themselves. ${ }^{13}$ It is clear, however, that during the Carolingian period in the ninth century and the so-called Gregorian reforms in the eleventh and early twelfth centuries there was intense clerical interest in the ritual in relation to larger debates about ecclesiology and sacrality. ${ }^{14}$ The purpose of this chapter is to consider the problems and possibilities of a variety of sources associated with church dedications and the methods that will help reveal the multiple possible meanings of these rites. We wish to emphasize that each dedication event would have had its own range of possible significances. ${ }^{15}$ For this reason we have divided the chapter into an initial section on the variety of the rites, and a second section on the interpretation of the rite through sermons. In discussing the rites we will use the term 'practised' in preference to the term 'performance', as the latter carries with it certain anthropological implications that emphasize rituals as being stable and reinforcing social stability. ${ }^{16}$ Ritual had the capacity to generate power, rather than simply reflect power within a community; therefore, this instability ought to be expected and needs to be examined. The rite - as practised in that particular moment - would have contributed to those significances. The particular practice depended not only on the rite available, but the church itself, and the topography of its setting. From the fifth century, sermons would have attempted to direct the meaning of the event for participants, although we cannot assume that was the significance a participant perceived. The participants themselves, in addition, would have consciously or unconsciously shaped the event. This is most clearly revealed in the historical record when participants oppose the dedication through violence,

13 The Pontifical of Charles de Neufchatel as transcribed in Leroquais, Pontificaux, 1: 77. Cited by Thomas Davies Kozacheck, 'The Repertory of Chant for Dedicating Churches in the Middle Ages: Music, Liturgy and Ritual', DPhil diss., Harvard University, 1995, 1. See also p. 16 above.

14 For the Carolingian period, see Iogna-Prat, La maison dieu; Collins, Carolingian Debate; and D. Polanichka, 'Transforming Space, (Per)forming Community: Church Consecration in Carolingian Europe', Viator 43 (2012): 79-98 (emphasizing the uniting force of the ritual); on the Gregorian reformers' efforts to shape the meaning of the rite, see Hamilton, Sacred City.

15 Hamilton intends a distinction between 'meaning' (that which may have been alluded to in rite, space or sermons) and 'significance' (that for which we have evidence as being perceived meaning by a participant). See Hamilton, 'Desecration and Consecration in Norman Capua, 1062-1122: Contesting Sacred Space during the Gregorian Reforms', Haskins Society Journal 14 (2003): 137-50.

16 As rightly observed in the introduction to The Appearances of Medieval Rituals, ed. Nils Holger Petersen et al. (Turnhout: Brepols, 2003). Throughout this article Hamilton is emphasizing ritual instability in the dedication and the manner in which rites attracted opposition, noting that sermons asserted a meaning often in line with the notion of social stability in performance theory. 
but their active support gave important force to the rite and made it important for the clergy to try to direct its meaning through sermons.

\section{Liturgical Rites}

Numerous studies concerning the dedication of churches have appeared in the last decade. ${ }^{17}$ As a rule, these analyses of the liturgy and its significance have been indebted to the so-called Ordo 40 found in the edition of the Pontifical romano-germanique as edited by Cyrille Vogel and Reinhard Elze. ${ }^{18}$ As Table 4.1 of Henry Parkes' article in this volume makes clear, Ordo 40 of the Vogel and Elze edition is a reconstruction based upon all nine of the manuscripts they consulted. It is contained in a tenth-century manuscript but is believed to be based on an earlier precedent. ${ }^{19}$ The Ordo prescribes a rite of approximately thirty-one steps. ${ }^{20}$

1. Vesting of the clergy.

2. Vigil with the relics, outside of the church and inside a tent with the sung litany.

3. Procession from the tent to the church with the relics.

4. Triple circuit around the church. The bishop sprinkles the walls with holy water and knocks on the main doors at each circuit, reciting the antiphon, Tollite portas.

5. The church doors are opened from the interior and the bishop enters with a few clergy.

6. Litany and prostration.

7. Inscription of Greek and Latin alphabets in ash on the floor of the church in a cruciform pattern (the abecedarium).

8. Preparation of the 'Gregorian Water'.

17 To name some of the more prominent recent studies contributing to the study of the significance of the dedication rite: Thomas Kozachek, 'Repertory'; Brian V. Repsher, The Rite of Church Dedication in the Early Medieval Era (Lewiston, NY: Edwin Mellen Press, 1998); Eric Palazzo, L'évêque et son image: l'illustration du pontifical au moyen âge (Turnhout: Brepols, 1999); Didier Méhu, Paix et communautés autour de l'abbaye de Cluny Xe-XVe siècle (Lyon: Presses universitaires de Lyon, 2001); Iogna-Prat, La maison dieu; Méhu, ed., Mises en scène et mémoires de la consécration de l'église dans l'occident médiéval (Turnhout: Brepols, 2007); Hamilton, Sacred City; Polanichka, 'Transforming Space'; Helen Gittos, Liturgy, Architecture, and Sacred Places in Anglo-Saxon England (Oxford: Oxford University Press, 2013), ch. 6.

18 PRG.

19 See Polanichka, 'Transforming Space', 85.

20 For a more complete description, see Hamilton, Sacred City, 13-50. 
9. Consecration of altar.

10. Aspersion of altar (seven times).

11. Aspersion of interior of church (three circuits).

12. Aspersion of length and width of interior.

13. Prayer of consecration.

14. Proceed to altar.

15. Preparation of mortar.

16. Incensing and anointing of altar with oil and chrism.

17. Anointing of interior walls with chrism.

18. Return to altar.

19. Incensing altar.

20. Prayer of consecration.

21. Blessing of linens, ornaments, vestments, etc.

22. Exit church to tent; change of vestments.

23. Prayers outside of doors; blessing of doors.

24. Process around exterior of church with laity.

25. Address to people, lord and constructor of church.

26. Entrance with relics.

27. Installation of relics into altar.

28. Anointing of altar with chrism.

29. Vesting of altar.

30. Illumination of church.

31. Mass.

The elaborateness of this rite as described in Ordo 40 clearly marks the space as distinct from others within the community. Scholars have expanded on this in multiple ways. Didier Méhu has observed that, in the dramatic example of Cluny, as dedicated by Urban II in 1095, the dedication rite, with its encircling of the church building, mirrored Cluny's own territorial circle of privilege, itself marked by a series of churches. ${ }^{21}$ In this case, the liturgy reflected and reinforced Cluny's position within the landscape. Dominique Iogna-Prat has argued that the dedication at Cluny, coinciding as it did with Urban's call for Crusade, and when placed in the larger context of a debate over the sacrality of place, also marked a particular ordering of society that was increasingly intolerant of religious difference. ${ }^{22}$ Moreover, this notion of sacred space as it developed primarily in the Carolingian era, but which came to the fore in the eleventh century, marked a rupture with early Christian notions of space, that Iogna-

21 Méhu, Paix et communautés, 152-65.

22 Iogna-Prat, Order and Exclusion: Cluny and Christendom Face Heresy, Judaism, and Islam (1000-1150) (Ithaca, NY: Cornell University Press, 2002), 168-79. 
Prat describes as in opposition to pagan notions of the sacred. ${ }^{23}$ Scholarship on the dedication, therefore, has emphasized how the rite marked communities of power, but it has paid less attention to the variety of ritual practice and, therefore, of meaning.

There was, however, a great variety in dedication rites and rarely can we be certain what rite was used where. For example, in southern Italy in the eleventh century, at least five different versions of the rite were available. ${ }^{24} \mathrm{~A}$ still greater number of forms of the rite can be found on the Italian peninsula in the eleventh century. If we consider, for example, the rite as found in the central Italian manuscript Biblioteca Apostolica Vaticana Latina 4770, from the late tenth or early eleventh century, it contains fewer than half of the steps named above. ${ }^{25}$ Its approximately fourteen steps share aspects of Ordo 40 but are in a different order: $6,3,5,15,10,3,26,27,28,29,11,30,31$ of those listed above. Absent from Vat. Lat. 4770 are the triple circuits of the exterior of the church (step 4), the anointing of the interior walls (step 17) and the tracing of the alphabets on the floor (step 7) among other steps found in Ordo 40. Their absence or inclusion surely altered the significance of the rite for the participants. These last two aspects of the rite were to be conducted by the bishop and his clergy while alone inside the church and so their absence or presence would have changed the significance of the rite for them. The triple circumambulation, however, and with it the aspersions of the exterior walls, engaged the entire community visually. Moreover, Vat. Lat. 4770 also lacks the second exterior procession around the church that we see in Ordo 40 (step 24 above). That procession was intended to include the entire congregation. Also absent from Vat. Lat. 4770 is the instruction for the bishop directly to address the 'lay lord and constructor' of the church. The absence of these steps would have dramatically diminished the participation of the laity. Without the triple exterior circuits and the aspersion of the exterior walls, the most visible signs of the dedication as a kind of baptism of the church were removed. ${ }^{26}$

23 The full argument is presented in his La Maison Dieu, but see also Iogna-Prat, 'Churches in the Landscape', in Early Medieval Christianities, ed. Thomas F.X. Noble and Julia M.H. Smith (Cambridge: Cambridge University Press, 2008), 363-79.

24 For comparative tables see Roger E. Reynolds, 'Les cérémonies liturgiques de la cathédrale de Bénévent', in La cathédrale de Bénévent, ed. Thomas Forrest Kelly (Ghent: Ludion, 1999), 167-205; and Hamilton, Sacred City, Tables 1-3, pp. 27-50.

25 See the description in Reynolds, 'Les cérémonies liturgiques', 167-205; John Boe and Alejandro Planchart, eds., Beneventanum Troporum Corpus 2: Ordinary Chants and Tropes for the Mass from Southern Italy, A.D. 1000-1250. Part 1 Kyrie Eleison, 2 vols. (Madison, WI: A-R Editions, 1989), 1:2.

26 Repsher, studying the commentary known as the Quid significent duodecim candelae, argues that it is an interpretation of Ordo 40 as a baptism. Others have argued from the form of the rite and from sermons that the rite was understood as a baptism of the church: Iogna- 
It should be remembered that liturgical texts are prescriptive, not descriptive sources. The rite may never have been practised as the pontifical said it must. Topography can provide important evidence in this regard. To give one example, churches built into mountainsides or existing infrastructure could not be readily circumambulated, if at all. Thus, in 1092, when Urban II dedicated Santissima Trinità at Cava, whose northern wall is partially built against the mountainside, it is difficult to imagine how a circumambulation could have been accomplished. ${ }^{27}$ A monastic complex provides other problems as well, with multiple structures (cloister, dormitories, etc.) physically attached to the church. Therefore it is hard to imagine the circumambulation of Montecassino by Alexander II in 1071, even though the pontifical copied out under Desiderius, abbot of Montecassino (c. 1026-87), required an exterior circuit with the populus singing the kyrie. ${ }^{28}$ The tenth-century manuscript produced at Montecassino or one of its dependencies, Montecassino, Biblioteca dell'Abbazia 451, contains Ordines 40 and 33, both of which call for exterior circumambulation..$^{29}$ It is possible, if $O r d o 33$ were used, that clerics (not Alexander) separately accomplished the one required exterior circuit, aspersing the church by means of a complicated route that would have taken them around the entire monastic complex and perilously close to the edge of the mountain itself. ${ }^{30}$ Perhaps three dangerous and complicated circuits around the monastic complex were made. Topography reminds us, then, that these are prescriptive sources and that ritual analysis, while desirable, must be done with caution when based on texts. ${ }^{31}$ In the broadest sense, the rite displayed the authority of the bishop and it clearly attempted to mark the church as set apart from the community as a whole. At a time when bishops were attempting to establish the 'Peace of God' (condemning violence against noncombatants and in sacred spaces) or their own position, the rite could have reinforced those themes. At the same time, a church's topographical location may indicate that it had a military or defensive purpose and was, despite the Peace, built in anticipation of its having a military role. ${ }^{32}$

Prat, La maison dieu; Lee Bowen, 'Tropology of Mediaeval Dedication Rites', Speculum 16 (1941): 469-79.

27 For the relationship of the church to the mountain, see Simeone Leone, 'La chiesa di

S. Alferio fondatore della badia di Cava', Benedictina 27 (1980): 393-416.

28 Rome, Biblioteca Apostolica Vaticana, Ms. Barberini latinus 631.

29 See Hamilton, Sacred City, 110.

30 Herbert Bloch, Monte Cassino in the Middle Ages, 3 vols. (Cambridge: Cambridge University Press, 1986), 1072, fig. 54.

31 See Hamilton, 'Les dangers du rituel', 159-61, 173.

32 Hamilton, 'Memory, Symbol, and Arson: Was Rome Sacked in 1084?', Speculum 78 (2003): 378-99. 
Without significant groups of people observing the rite, it must be noted, the rite would have been an impotent means to assert the bishop's authority or social norms, such as the Peace. We do have substantial evidence that rites did sometimes involve large numbers of clerics and laity from across the social spectrum..$^{33}$ Suger, abbot of Saint-Denis (France, 1122-51) reported that the crowds at the dedication of Saint-Denis were so great that during the rite of aspersing the exterior of the church the king and his soldiers beat back the crowd with branches and sticks in order to protect the doors; elsewhere Suger describes the crowd as forming a more joyful, more decorous procession: both may be true. ${ }^{34}$ Bruno of Asti, bishop of Segni, cardinal legate, and abbot of Montecassino (d. 1123), observed in passing that it was fitting that 'large throngs of people gathered at the dedication of churches. ${ }^{35}$

Clerics associated with these churches would tend to record the pious enthusiasm of the crowds who assembled at the dedication of a church and so their accounts should be treated with caution especially when lacking in detail. However, there is also evidence for resistance to both the building and the consecration of churches that may be considered more reliable. For example, in Italy, in a twenty-year period in the eleventh century, four different papal dedications were marked by some form of violence or threat of violence, in Bari (1092), Parma (1104), Modena (1106) and Capua (1108). The situations varied. In Bari in 1087, a group who stole the relics of St Nicholas (a group that included clergy, children of clergy, nobles, boni homines - civic notables of legal standing, merchants and sailors) fought a skirmish with, and defeated, the bishop's armed men in order to retain control over the relics and the right to build their own church for them. This group had already formed an alliance with a local abbot, Elias, who would later be consecrated bishop by Urban II, who also dedicated the church of San Nicola. ${ }^{36}$ Thus, there were no clear divisions in Bari along civic or religious lines. In Modena, a group of eighteen armed

33 The evidence for eleventh-century Italy is discussed in detail in ch. 2 of Hamilton, Sacred City.

34 It is not entirely clear if the king and his retinue only were impeded by the crowd, or if the crowd was also impeding the rite although that seems most probable. Suger, De consecratione, in Abt Suger von Saint-Denis ausgewählte schriften: Ordinatio, De consecratione, De administratione, ed. Andreas Speer and Günther Binding. (Darmstadt: Wissenschaftliche Buchgesellschaft, 2000), 242; Suger, De administratione, in Abt Suger, 322. See also Suger, Oeuvres 1, ed. and trans. Françoise Gasparri (Paris: Les Belles Lettres, 1996), 44-47, $114-$ 15; Günther Binding and Andreas Speer, Abt Suger von Saint-Denis, De consecratione; kommentierte Studienausgabe (Cologne: Abt. Architekturgeschichte, 1995); and Abbot Suger: On the Abbey Church of St-Denis and Its Art Treasures, ed. and trans. Erwin Panofsky (Princeton: Princeton University Press, 1946).

35 Bruno of Segni, Libri sententiarum, PL 165: 879c.

36 This is discussed in detail in Hamilton, Sacred City, 135-42. 
knights and citizens, apparently mistrusting Matilda, countess of Tuscany, were permitted to be present at the deposition of the relics of St Geminiano into the altar of the basilica during the consecration. The rite was led by Pope Paschal II and among those present were Matilda, the new bishop, Dodo, and the architect Lanfranc along with the armed knights and citizens. It should be recalled that the deposition of the relics, according to every dedication rite from the period that I have studied, was supposed to take place only in the presence of the bishop and his clergy and certainly not an armed group of the laity. Thus, the explicit threat of violence was accommodated in the practice of the rite at Modena. ${ }^{37}$

In two other cases, Parma and Capua, a recently consecrated space elicited violence and destruction. In Parma in 1104, people destroyed a chapel Matilda built within the recently rebuilt cathedral, in opposition to an anti-imperial and reformist sermon preached by the papal legate. It was clear that the chapel represented Matilda's local authority, and a strong military response from her was required to exact payment for the damage and restore her authority ${ }^{38}$ In Capua, a chapel dedicated by Bruno of Segni in 1106 at Sant'Angelo in Formis (a few miles outside the city) was destroyed by soldiers of Sennes, archbishop of Capua. Sennes probably considered the dedication of a church closely linked to Montecassino by Bruno, then bishop of Segni and abbot of Montecassino, as a threat to his regional episcopal authority.

This example from Capua introduces another aspect of the rite's possible meanings, that given to it through its architecture and art. ${ }^{39}$ In the case of Sant'Angelo, the very large image in the church's apse fresco of its builder, Abbot Desiderius (later Victor III, 1086-87), emphasized the authority and presence of the abbey of Montecassino in and around Capua. Interestingly, not

37 Hamilton, Sacred City, 187-95.

38 Hamilton, Sacred City, 196.

39 Examples of studies of art and architecture of particular interest to dedication rites include: Lucy E.G. Donkin, 'Usque ad ultimum terrae: Mapping the Ends of the Earth in Two Medieval Floor Mosaics', in Cartography in Antiquity and the Middle Ages: Fresh Perspectives, New Methods, ed. Richard J.A. Talbert and Richard Watson Unger (Leiden: Brill, 2008), 189-218; Cécile Treffort, 'Une consécration “à la lettre”. Place, rôle et autorité des textes incrits dans la sacralisation de l'église', Mises en scène, ed. Méhu, 219-52; Yann Codou, 'La consésecration du lieu de culte et ses traductions graphiques: inscriptions et marques lapidaires dans la Provence des XIe-XIIe siècles', in Mises en scène, ed. Méhu, 25384; Donkin, 'Mosaici pavimentali medievali nell'Italia settentrionale e i loro rapporti con la liturgia', Atti del X Convegno dell'Associazione Italiane per lo Studio e la Conservazione del Mosaico (Tivoli: Edizioni Scripta Manent, 2005), 503-14; Elizabeth C. Parker, 'Architecture as Liturgical Setting', in The Liturgy of the Medieval Church, ed. Thomas J. Heffernan and E. Ann Matter (Kalamazoo: Western Michigan University, 2001), 273-326; Nancy Spatz, 'Church Porches and the Liturgy in Twelfth-Century Rome', in Liturgy of the Medieval Church, 327-67. 
only did Paschal II censure Sennes, but he also joined Bruno in dedicating the church of San Benedetto in Capua in 1108. In this manner, Bruno and Paschal clearly employed the rite of consecration to reassert Bruno's authority. ${ }^{40}$ These examples of participation in the rite expressed through violent opposition reveal the significance such rites could have and the diversity of interpretations of them and reactions to them. They also demonstrate the variety of views that could be held about these ceremonies in which monks and laity were pitted against bishops, the laity were confronting the reforming popes, and popes were confronting bishops. Clearly power was at stake in the consecration, but this was not a fixed performance with a fixed conclusion; it had no single 'function'.

If, as suggested, there is no single meaning for the rite and it was not uniformly practised, then clerical efforts to direct it or guide interpretation of it must be understood as precisely that, the efforts by a specific cleric to create significance for the rite for a specific audience. That a sermon or commentary attempted to shape the meaning of a rite reveals that it was clearly perceived as significant and worth shaping. Moreover, the emphasis placed on the rite in sermons and in liturgical sources during the Carolingian and Gregorian periods reflects an effort to assert meaning through ritual practice and interpretation, an effort whose success depended on the many factors discussed above that were largely beyond the control of papal or imperial authorities. Even though it can be difficult to connect a specific sermon to a specific rite, sermons, however, remain a central piece of evidence in the effort to shape the meaning of a particular church and it is to those that we now turn. ${ }^{41}$

\section{Sermons}

What did church dedication rites signify to medieval people? Which texts are we to turn to if we want to find out? The ordines spring to mind. They define the course of the rite and hint at symbolic connotations through biblical motifs evoked in readings and chants. But, as sources for significance, they pose two problems. How the rite ought to be performed is not the same as how it was actually practised, ${ }^{42}$ and even if it was carried out by the book, the liturgy

40 See Hamilton, 'Desecration and Consecration in Norman Capua', 143-50; and Hamilton, Sacred City, 200-1.

41 A good example of the possibilities and limits of such an effort can be seen in Ugo Facchini, 'I sermoni In cena Domini ed In dedicatione ecclesiae di san Pier Damiani. Esame della ritualità, Benedictina 54 (2008): 212-32.

42 On this general scholarly challenge, see, for example, Paul F. Bradshaw, The Search for the Origins of Christian Worship: Sources and Methods for the Study of Early Liturgy, 2nd ed. (Oxford: Oxford University Press, 2002), 1-20. Concerning dedication, see Hamilton, Sacred City and 'Les dangers du rituel', 159-88. 
prescribed in the ordines is not the liturgy experienced by the participants. One part of the dedication was an inclusive and elaborate eight-day celebration with public processions and masses. ${ }^{43}$ But much of the central activity, the anointings, the writing of the alphabet on the floor and so on, took place behind closed doors, involving only the bishop and his officiants. ${ }^{44}$

Other types of sources give a better sense of how the dedication was perceived, for example charters, chronicles and vitae. ${ }^{45}$ This chapter focuses on the expositions in commentaries and sermons. First I examine a set of key motifs transmitted in early and high medieval texts, showing the meaning generally ascribed to the dedication. Secondly, I present three sermons that show the variation prompted by individual contexts and concerns.

\section{Rite and Interpretation}

Scholars of church dedication rituals stress the connection between contemporaneous liturgical rites, sermons and commentaries. ${ }^{46}$ But sermons and commentaries are also connected to a prolific tradition of liturgical interpretations that serve not only to explain the liturgy, but also to mould Christian belief. They establish connections that reach backwards towards biblical origins and forwards towards eschatological fulfilment.

Early Christian and medieval liturgical interpretations hinged on allegorization. The platonically based pursuit of allegorical meaning occurs in the New Testament, but as a Christian interpretative strategy it was developed by Origen above all. ${ }^{47}$ Origen's exegesis interpreted Old Testament books in

43 See Hamilton, 'To Consecrate the Church: Ecclesiastical Reform and the Dedication of Churches', in Reforming the Church before Modernity: Patterns, Problems, and Approaches, ed. C. Bellitto and L. Hamilton (Aldershot: Ashgate, 2005), 105-37, at 106-7 (early Middle Ages); Ruth Horie, Perceptions of Ecclesia: Church and Soul in Medieval Dedication Sermons (Turnhout: Brepols, 2006), 10-12 (historically unspecific).

44 Emphasized in Margrete Syrstad Andås, 'Art and Ritual in the Liminal Zone', in The Medieval Cathedral of Trondheim: Architectural and Ritual Constructions in their European Context, ed. Margrete Syrstad Andås et al., Ritus et artes: Traditions and Transformations 3 (Turnhout: Brepols, 2007), 47-126, at 59-60.

45 For example, Michel Lauwers, 'Consécration d'églises, réforme et ecclésiologie monastique', in Mises en scène, ed. Méhu, 93-142, see also Méhu, 'Historiae et imagines', in ibid., 15-48, at 40-44; Hamilton, Sacred City and 'Les dangers du rituel'.

46 For example Méhu, 'Historiae et imagines', 32.

47 Especially Galatians 4: 21-26 on Hagar and Sarah as allegories of the two covenants. The classic work is Henri de Lubac, Medieval Exegesis: The Four Senses of Scripture (Grand Rapids: W.B. Eerdmans, 1998; first publ. in French 1959); more accessible are Beryl Smalley, The Study of the Bible in the Middle Ages (Oxford: Blackwell, 1952 and later), 1-26; Daniel Boyarin, 'Origen as Theorist of Allegory: Alexandrian Contexts', in The Cambridge Companion to Allegory, ed. R. Copeland and P.T. Struck (Cambridge: Cambridge University 
the light of the New Testament and argued that these texts are imbued with spiritual meanings beyond the straightforward literal or historical ones. Thereby texts remote in time and tenor became potentially relevant for all ages. The spiritual meanings came to be structured in three categories: the allegorical meaning speaks of Christ and the Church, the tropological or moral meaning offers guidelines for the Christian's conduct and the anagogical meaning deals with the afterlife. Read in this light, next to their literal meaning, biblical texts contain messages for each believer concerning belief, behaviour and beatitude. The four-fold approach is related to typology: the idea that the Old Testament prefigures the New while the New Testament fulfils the promise of the Old. ${ }^{48}$ Owing to Fathers such as Ambrose, Augustine and Gregory the Great the typological-allegorical understanding came to permeate the religious mindset up to and including Dante.

\section{General Motifs}

Commentaries and sermons are important vehicles of liturgical interpretation. Those concerned with the dedication tend to focus on the constituents of the Church, and from the Carolingian age such interpretations became crucial frameworks for ecclesiological reflection. ${ }^{49}$ Many commentaries and sermons on the dedication therefore come across as doctrinal compendia.

Scholars tend usually to read such commentaries and sermons as on a par. This chapter suggests that, while thematically related and both concerned with the spiritual and moral ramifications of the rite, commentaries and sermons abide by very different generic conventions. ${ }^{50}$ The liturgical commentary is a strictly literary genre. ${ }^{51}$ Some commentaries on church dedication rites, such as the Carolingian Quid significent duodecim candelae, stay close to the liturgy. ${ }^{52}$ Others, such as Honorius of Autun's (d. 1154) Gemma Animae, with its nuptial

Press, 2010), 39-54; and Denys Turner, 'Allegory in Christian Late Antiquity', in ibid., 7182.

48 Such as the crossing of the Red Sea as a type of Christ's Passion and the purging of sin in each individual baptism; Augustine, De catechizandis rudibus, 20.34: OEvres de Saint Augustin 11/1: La première catéchèse, de catechizandis rudibus, trans. Goulven Madec (Paris: Etudes augustiniennes, 1991), 166-68.

49 Méhu, 'Historiae et imagines', 28.

50 Exemplified in Eric J. del Giacco, 'A Comparison of Bede's Commentary and Homilies on Luke', Medieval Sermon Studies 50 (2006): 9-29.

51 Treatises such as Ambrose's De sacramentis, Isidore of Seville's De ecclesiasticis officiis and Amalarius of Metz's commentaries, such as Expositio Missae and Liber officialis; for more examples see Méhu, 'Historiae et imagines', 28-32; Iogna-Prat, La maison dieu, 285.

52 Published as Tractatus de dedicatione ecclesiae by Remigius of Auxerre in PL 131:84566; an English translation appears in Repsher, Rite of Church Dedication. 
vocabulary, are more independent. ${ }^{53}$ By contrast, the sermon grows out of an oral situation. ${ }^{54}$ Homiletic treatment of the dedication appears in sermons written for the annual feast of the dedication of the Jewish Temple, for the dedication of a church proper ${ }^{55}$ and for the annual eight-day commemoration of the dedication instituted by Felix IV (526-30). ${ }^{56}$

It is true, however, that commentaries and sermons on the dedication share motifs. Both genres take their thematic cue from the dedication liturgy and, via four-fold interpretations, develop an array of themes whose spiritual connotations add further dimensions to the here and now of the rite. ${ }^{57}$ The interpretations focus on fundamental doctrinal themes that are not particular to this rite. In the context of the dedication they are generally couched in a metaphorical vocabulary that favours architectural and spatial images as well as biblical references to building and building materials. A summary overview of key categories, motifs and biblical references will suffice:

Typology This category inscribes each community in salvation history. The church is associated with Solomon's Temple (1 Kings 7-8), ${ }^{58}$ occasionally with a reference to the Temple as an inferior antecedent of the Church. ${ }^{59}$ Sometimes an added typological dimension is offered through references to Moses' Tabernacle or to the description of the feast of the dedication of the Temple (John 10). ${ }^{60}$ The typological tenor is augmented through allusions to Jacob's dream and its

53 Gemma Animae 1.150; PL 172:590. The allusion to the wedding between Christ and the Church is based on Eph. 5: 21-27; Lauwers, 'Consécration d'églises', 114.

54 See Beverly M. Kienzle, 'Medieval Sermons and Their Performance: Theory and Record', in Preacher, Sermon and Audience in the Middle Ages, ed. C. Muessig (Leiden: Brill, 2002), 89-124.

55 OR 40 prescribes a sermon after the triple procession with the relics.

56 Felix IV, Epistula 2, PL 65:16-21, including a full quotation of 1 Kings 8 on the Temple; see also Iogna-Prat, La maison dieu, 292; Repsher, Rite of Church Dedication, 20-21.

57 Finbarr C. Clancy, 'Augustine's Sermons for the Dedication of a Church', in Papers Presented at the Thirteenth International Conference on Patristic Studies, ed. M.F. Wiles and E.J. Yarnold, Studia Patristica 38 (2001): 48-55, at 48-50.

58 Augustine, De civitate Dei, 18.48; or to the synagogue as inferior to the church, Quid significent duodecim candelae, 5. These are but representative texts; for additional examples, see, for the early Middle Ages, Hamilton, Sacred City; Repsher, Rite of Church Dedication; for the late Middle Ages, see Horie, Perceptions of Ecclesia.

59 Hilary of Poitiers, De dedicatione ecclesiae, PL 10:881-83; Bede, Homilia 21, PL 94:247-8; Homilia 45, PL 94:434; Peter Damian, Sermo 72.9, PL 144:910.

60 For the Tabernacle, see Bede, Homilia 45, PL 94:434; Hrabanus Maurus, De institutione clericorum, 2.45, PL 107:358-9; Homilia 39, PL 110:73-4. The reference to John appears in Isidore of Seville, De origine officiorum 36.1, PL 83:771, reiterated in Hrabanus Maurus, De institutione clericorum 2.45, PL 107:358. See also Bede, Homilia 21, PL 94:243-49; Ivo of Chartres, Decretum 3.24, PL 161:204. The twelve-year-old Jesus in the 
epiphany, grasped in the statement 'This place is terrifying' (locus iste terribilis est, Gen. 28:17), cued by readings in the rite.

Christology (The 'Allegorical' Meaning) Allusions to the Christological implications of the dedication are complex and varied. They range from deliberations on Christ's passion and resurrection ${ }^{61}$ to architectural images such as Christ as foundation (1 Cor. 3:11) and cornerstone (Ps. 117:22; Eph. 2:20-22). ${ }^{62}$

Ecclesiology (The 'Allegorical' Meaning) The fundamental association between church (building) and Church (community) is present already in Eusebius's (d. c. 340 ) presentation of the Constantinian surge of dedications. ${ }^{63}$ This association is reinforced with references to 1 Peter 2:4-5 (the Christians as living stones) or to Matthew 16:18 (Peter as the rock on which Christ built his Church) and elaborated with masonic metaphors. ${ }^{64}$ Ecclesiological motifs create relations between communities across time and space, including Jews and pagans. ${ }^{65}$ Both the Christological and the ecclesiological motifs are often developed in association with allegorical interpretations of parts of the church building or other architectural allegories. ${ }^{66}$

The Christian (The 'Moral' Meaning) References to individual believers appear in the earliest expositions of the consecration. ${ }^{67}$ The church is described

Temple (John 10: 24) is exploited allegorically in Bede, Homilia 21, PL 94:244; Hrabanus Maurus, Homilia 40, PL 110:74-75.

61 Augustine, Sermo 163.3, PL 38:890; Sermo 336.3-5, PL 38:1473-75; Bede, Homilia 21, PL 94:244-45.

62 Eusebius, Historia ecclesiastica 10.4; Bede, Homilia 45, PL 94:436; Haymo of Halberstadt, Homilia 141, PL 118:746 (defined by Henri Barré as Haymo of Auxerre in Les homéliaires carolingiens de l'école d'Auxerre (Vatican City: Biblioteca Apostolica Vaticana, 1962), 61.

63 Eusebius, Historia ecclesiastica 10.3. See also Hilary of Poitiers, De dedicatione ecclesiae, PL 10:881; Bede, Homilia 21, PL 94:248; Homilia 45, PL 94:434.

64 Méhu, 'Historiae et imagines', 37.

65 Augustine, De civitate Dei 18.48; Bede, Homilia 45, PL 94:434; Hrabanus Maurus, De universo 14.23, PL 111:401; Bruno of Segni, Expositio in Exodum 26, PL 164:318; Hugh of Saint-Victor, De sacramentis II.5.1, PL 176:439. Another form of historization appears in claims that the command to build churches was Christ's requirement to his disciples; Lauwers, 'Consécration d'églises', 117-21.

66 Commentaries on Ezechiel, including his vision of the Temple; Bede's De templo and De tabernaculo; Hrabanus Maurus, De universo 14; G. Turville-Petre, 'The Old Norse Homily on the Dedication', Medieval Studies 11 (1949):206-18, at 207.

67 Repsher, Rite of Church Dedication, 25 with reference to Ambrose's Exhortatio ad virgines, PL 16:380. 
as being baptized into the universal Church in parallel with the baptism of the individual into the community. ${ }^{68}$ Tropological or moral interpretations create links between the dedication and the Christian as God's temple (1 Cor. 3:16-17 and 6:19; 2 Cor. 6:16) ${ }^{69}$ and latch on to associations between the Lord's temple and Christ's body (John 2:21)..$^{70}$ This theme is developed ecclesiologically in the idea that the Church consists of the community of individual temples of the Lord. ${ }^{71}$

Eschatology (The 'Anagogical' Meaning) The anagogical reading of the dedication turns towards beatitude. Authors emphasize the provisional character of the church building: what has been begun on earth will be completed in heaven. ${ }^{72}$ The expositions stress the superiority of beatific immortality over earthly transience (1 Cor. 15:55-57) in representations of the heavenly abode which surpasses any earthly construction. ${ }^{73}$

The four-fold interpretation becomes a catalyst for expositions that position each church, community and believer within the Church and its comprehensive system of belief and which manifest the church building as the physical structure within which all of this is contained.

\section{Three Sermons}

These motifs are orchestrated in a variety of keys and degrees of sophistication. They are coloured by the theological mindset of individual authors, by the audience, as well as by institutional, social and textual conditions. The antiarian Hilary of Poitiers (c. 300-c. 368) employs his dedication sermon to talk about the Trinity, while Augustine (354-430) uses one of his to propagate

68 Ivo of Chartres, Sermo 4; Repsher, Rite of Church Dedication, 17.

69 Eusebius, Historia ecclesiastica 10.4; Augustine, Sermo 163.1, PL 38:889; Bede, Homilia 21, PL 94:244; Hrabanus Maurus, Homilia 40, PL 110:75; Peter Damian, Sermo 72.11, PL 144:910. For associations of body and temple, see Harris, 'Body as Temple'.

70 Eric Palazzo, Liturgies et société au moyen âge (Paris: Aubier, 2000), 72.

71 Repsher, Rite of Church Dedication, 29-30.

72 Augustine, Sermo 336.1, PL 38:1473; Sermo 337, PL 38:1475-78, both arguing that believers, as houses of God, are built in this life and dedicated in the next; Hilary of Poitiers, De dedicatione ecclesiae, PL 10:884; Bede, Homilia 21, PL 94:245-46 and 248; Homilia 45, PL 94:434; Hrabanus Maurus, Homilia 40, PL 110:75-76.

73 Augustine, Sermo 163.7-12, PL 38:892-95; Bernard of Clairvaux, In dedicatione ecclesiae, sermo 4.4-6: Bernhard von Clairvaux: Sämtliche Werke, ed. Gerhard Winkler et al., 10 vols. (Innsbruck: Tyrolia Verlag, 1997), 8:840-46; Sancti Bernardi opera, ed. Jean Leclerq, Henri Rochais and Charles Talbot, 8 vols. (Rome: Editiones Cistercienses, 1957-77), 5: 385-88. 
his anti-pelagian programme. ${ }^{74}$ The interpretations hover in a tension between their shared adherence to an interpretative tradition and their individual historical context.

The meaning of the dedication is taught in both commentaries and sermons. But sermons are driven by a more acute communicative compulsion. ${ }^{75}$ Méhu distinguishes between sermons inserted in historical narratives and the polished works by named authors, but even the latter, I argue, maintain a connection with the preaching situation, however stylized..$^{76}$ In its written form the sermon is defined by literary conventions and even allusions to oral practice may belong to a carefully crafted literary strategy. ${ }^{77}$ At the same time sermons address, at the very least, an implied audience and by turning to sermons we approach the interpretative community for whom each of these texts made particular sense. This is an approach which is interested in the reader-response anticipated or prompted in a text and the questions in the audience which the author sought to answer. ${ }^{78}$ If we examine three sermons, one for the dedication proper, two for its annual commemoration, we shall see that while all are permeated by the four-fold interpretation, their juxtaposition illustrates how understandings of the dedication vary from one text to another.

\section{The Stave Church Sermon}

We begin with the latest sermon of the three. The so-called 'Stave church sermon', an Old Norse homily for the dedication, is transmitted in Old Norse and Icelandic manuscripts from around 1200 to 1220 , but the material is probably older. ${ }^{79}$ Possibly a model sermon whose architectural description is

74 Gert Partoens, 'Prédication, orthodoxie et liturgie', in Prédication et liturgie au moyen âge, ed. N. Bériou and F. Morenzoni (Turnhout: Brepols, 2008), 23-51, at 50.

75 On medieval sermons, see B.M. Kienzle, ed., The Sermon, Typologie des sources du moyen âges occidental 81-83 (Turnhout: Brepols, 2000); and, briefer, Ann T. Thayer, 'The Medieval Sermon', in Understanding Medieval Primary Sources: Using Historical Sources to Discover Medieval Europe, ed. J.T. Rosenthal (London: Routledge, 2012), 43-58.

76 Méhu, 'Historiae et imagines', 37.

77 See, for example, Bernard McGinn, 'Introduction', in Isaac of Stella: Sermons on the Christian Year, trans. H. McCaffery (Kalamazoo, MI: Cistercian Publications, 1979), xvii; Bernard of Clairvaux: Sermons for the Summer Season, trans. B.M. Kienzle (Kalamazoo, MI: Cistercian Publications, 1991), 4-6.

78 Related to the idea of the Erwartungshorisont addressed in a text, see Hans Robert Jauss, 'Literaturgeschichte als Provokation der Literaturwissenschaft', in Literaturgeschichte als Provokation (Frankfurt am Main: Suhrkamp, 1974), 144-207, esp. 183-89.

79 I am grateful to Nils Holger Petersen for his reference to this sermon. In its complete form it has been transmitted in two Icelandic and one Old Norse manuscripts; Hans BekkerNielsen, 'The Old Norse Dedication Liturgy', in Festschrift für Konstantin Reichardt, ed. C. 
sufficiently vague to apply generally, ${ }^{80}$ this homily does not speak of the rite, but offers an allegorical interpretation of the church building. ${ }^{81}$ As a catalogue of commonplaces it makes a useful point of departure.

The sermon begins with Solomon's Temple in a paraphrase of 1 Kings 8-9 and then turns to the present community: 'From these origins, churches and all the celebration of dedication days began. And since, dear brethren, we are holding the feast of dedication today, it is of first importance that we realize how great is the grace we receive in the church. ${ }^{82}$ The author stresses how the church building and the grace bestowed inside it frame the life of a human being: baptism, the Eucharist, human beings' reconciliation with God, prayers and, when sin is so grave that God's friendship is lost, confession, as well as, finally, the funeral. ${ }^{83}$ The meaning is expounded in pedagogic vein, associating the Christian community with the hall of God (1 Cor. 6:19). First, the parts of the building are interpreted as an image of the different peoples who share the Christian faith; the Christians who are already with God (signified by the choir) and those still on earth (the nave). The altar is Christ, and the entry to the church is the right faith that leads believers into the Christian community. The floorboards are the humble: the more they are trodden on, the more they

Gellinek with H. Zauchenberger (Bern: Francke Verlag, 1969), 127-34, at 127-28. An edition of the Old Norse text has been published as Gamal Norsk Homiliebok, ed. Gustav Indrebø (Oslo: Oslo Universitetsforlaget, 1966; first publ. 1931). Turville-Petre’s English translation is published in 'The Old Norse Homily', 206-18, at 215-18. The homily was previously dated to the early twelfth century, but recent research associates it with the beginning of the thirteenth century when preaching to lay people became a consolidated practice; Arnved Nedkvitne, Lay Belief in Norse Society 1000-1350 (Copenhagen: Museum Tusculanum Press, 2009), 52-53. However, the earlier dating is maintained in Kirsten M. Berg, 'On the Use of Mnemonic Schemes in Sermon Composition: The Old Norwegian Homily Book', in Constructing the Medieval Sermon, ed. Roger Andersson (Turnhout: Brepols, 2007), 221-36, at 232. On the commemoration of the dedication according to the Nidaros ordinal, see Andås, 'Art and Ritual', 60; on dedication in the Old Norse context see Andås, 'Imagery and Ritual', 85-91 and 119-22.

${ }^{80}$ Although Turville-Petre sees the absence of the commonplace reference to living stones as a pointer to the wooden construction typical of stave churches; 'Old Norse Homily', 209.

81 Bekker-Nielsen, 'Old Norse Dedication Liturgy', 130. Influences can be traced from, among others, Richard of Saint-Victor's homilies on the dedication, Honorius of Autun's Gemma Animae and Hrabanus Maurus's De universo; Gammelnorsk Homiliebok, ed. Erik Gunnes, trans. Astrid Salvesen (Oslo: Universitetsforlaget, 1971), 176; Turville-Petre, 'Old Norse Homily', 207-11.

82 'Old Norse Homily', 215; this part is influenced by Origen's De tabernaculo, in part transmitted via Bede’s De templo; Gammelnorsk Homiliebok, 176.

${ }^{83}$ It is worth bearing in mind that also secular reconciliations could take place in the church; Nedkvitne, Lay Belief, 92; Andås, 'Imagery and Ritual', 151-55. 
bear the weight of the Christians. The long walls are the pagans and the Jews, the cross wall at the West is Christ who unites them and the rood-screen the Holy Spirit by way of which one passes into heaven. The corner posts are the gospels and the roof an image of the believer who looks towards heaven. ${ }^{84}$

Midway through the sermon, the author shifts focus from Christianity at large to the individual Christian 'who verily makes himself the temple of the Holy Spirit by his good works. For every man shall fashion a spiritual church within himself, not with timbers or stones, but rather with good works. ${ }^{35}$ In this church the choir is prayer and psalms and the altar love, the cross walls are the love of neighbour (the outer wall) and of God (the inner). The entry into this church signifies control of the tongue. The corner posts are the key virtues: wisdom, justice, strength and temperance; the floorboards are humility and the roof is hope. The crucifixes are the burdens laid on our bodies in fasts and vigils. The sermon ends on an anagogical note: 'it is for this reason that we celebrate the feast of dedication annually on earth, that we may celebrate an eternal day of dedication, which is true rejoicing of all the saints in heaven. ${ }^{36}$ The road to this eternity goes by way partly of charity towards the neighbour: bemoan and punish them for their sins, help them in their needs; partly of tending to the souls of the dead with prayers. ${ }^{87}$

With a focus on the building the preacher has a material point of reference at hand: a physical anchoring of his instruction that aids memorization. ${ }^{88}$ The architecture provides a spatial structure which sustains messages both about relations (Christ mediating between Jews and pagans as a cross wall between two long walls) and about movement (the entry into the church, that is, via faith into the community, or the progression from nave to choir, that is, from life to death) and which allows for a coherent doctrinal structure which embraces widely different components: communal and individual, historical and contemporary, material and spiritual.

84 'Old Norse Homily', 216.

85 'Old Norse Homily', 216.

86 'Old Norse Homily', 217.

87 'Old Norse Homily', 218. In his three dedication homilies Richard of SaintVictor presents an interpretation which resembles the 'Stave church sermon's' but has more theological finesse, including both the imago Dei and the five senses of the soul; PL 177:901-07; Hideki Nakamura, 'Talem vitam agamus, ut Dei lapides esse possimus: Kirchweihpredigten Richards von Sankt Viktor', in 'Das Haus Gottes, das seid ihr selbst': Mittelalterliches und barockes Kirchenverständnis im Spiegel der Kirchweihe, ed. R.M.W. Stammberger and C. Sticher (Berlin: Akademie Verlag, 2006), 293-327.

88 Berg, 'On the Use of Mnemonic Schemes. The homily comes across as an accessible counterpart to Hugh of Saint-Victor's ark of Noah; see Mary Carruthers, The Book of Memory: A Study of Memory in Medieval Culture (Cambridge: Cambridge University Press, 2008; first publ. 1990), 53-55. 
The sermon rehearses standard motifs. It goes through allegorical, tropological and, albeit less elaborately, anagogical explications of the church. When searching for the specificities of this model sermon, we may notice, parenthetically, the striking difference between the preacher's anticipation of the community's intent focus on the architecture and the sagas' descriptions of the general coming and going during mass. ${ }^{89}$ Putting aside whether it was listened to or not, the sermon stresses the role of the church in human life as the locus of baptism, confession and burial, and gives clear-cut directions concerning charity for the needy and prayers for the dead. The church is positioned at the centre of the community's life, embracing generations and social segments. The dedication ceremony is present only tacitly as the initiation of the relation between God and the congregation which is manifested in the church and which has a bearing on individual and familial life cycles as well as the daily conduct for which the listeners would expect guidelines.

\section{Ivo of Chartres: Sermo 4, De sacramentis dedicationis}

Ivo of Chartres (c. 1040-1115) was prior of the Abbey of Saint-Quentin (France) from 1069 to 1090 when he became bishop of Chartres. He was an influential author of texts on canon law, working under the auspices of Gregorian reform..$^{90}$ Ivo's Sermo 4, De sacramentis dedicationis, is written for a dedication proper. ${ }^{11}$ This is not yet a familiar space, but the preacher invests it with a meaning that relates it to the believers, employing baptism as the central point of identification. The sermon is closely connected to the sacramental ponderings in the bishop's remaining oeuvre and to his reform agenda; as Louis Hamilton has demonstrated, the dedication feast is well suited to this end. ${ }^{92}$ It is indicative of the sermon's doctrinal character that several of Ivo's points were taken over in Hugh of Saint-Victor's De sacramentis, including the dedication as the sacramental framework for all other sacraments. ${ }^{93}$ This raises, again,

89 Nedkvitne, Lay Belief, 94-95.

90 For Ivo's biography, see Christof Rolker, Canon Law and the Letters of Ivo of Chartres (Cambridge: Cambridge University Press, 2010), 1-49; Margot E. Fassler, The Virgin of Chartres: Making History through Liturgy and the Arts (New Haven: Yale University Press, 2010), 133-36; Bruce C. Brasington, 'Lessons of Love: Bishop Ivo of Chartres as Teacher', in Teaching and Learning in Northern Europe, 1000-1200, ed. S.N. Vaughan and J. Rubenstein (Brepols: Turnhout, 2006), 129-47.

91 PL 162:527-35.

92 See above and Hamilton, Sacred City; Fassler, Virgin of Chartres, 136-40.

93 Desacramentis II.5.1, PL 176:439; Margot E. Fassler, Gothic Song: Victorine Sequences and Augustinian Reform in Twelfth-Century Paris (Cambridge: Cambridge University Press, 1993), 333-34; Hanns P. Neuheuser, 'Ritus und Theologie der Kirchweihe bei Hugo von St. Viktor', in 'Das Haus Gottes', 251-92, esp. 273-76. 
the question of genre. Méhu argues that the most theoretical sermons on the dedication do not differ substantially from treatises. ${ }^{94}$ But even with the flux in generic definitions in mind, an identification as sermo and its particular connotations are not to be lightly dismissed - no matter how theoretical the text. Ivo's sermon feeds rhetorically on the implied presence of an audience: a community who shares the view of the bishop knocking on the church door and partakes in the festivities. The sermon has a speech-act character that unites the community, the feast and the Scripture differently from a treatise.

Ivo addresses his audience directly: 'Since you have come devoutly to the dedication of this basilica today, it is necessary that you understand that what you see done to this saintly man-made [edifice] has all been fulfilled in you. ${ }^{95}$ His ample introduction reminds them that through baptism they have been made temples of the Lord, athletes of Christ, dedicated to a life-long combat against the devil. This sacramental association flavours the entire sermon which revolves around two powerful images. The first is the dedication as a mimesis of baptism: 'We circulate and asperse the church with water on the outside because when there cannot be a triple immersion [of the church] in the same way as of those baptized, it is necessary that there is a triple aspersion so that we can make it resemble the sacrament. ${ }^{96}$ The second is the entry of the bishop which is presented as a critical exorcistic moment. Bearing in mind Ivo's inclination for reform, it is unsurprising that he lingers over episcopal power: the bishop's admission into the church is described as a veritable conquest. Ivo ponders the 'Quis est iste rex gloriae?' (Who is this king of Glory?) of Psalm 24 which sounds from within the church when the bishop knocks after each circulation. The voice of the Psalm - and of the deacon from inside the church - is ascribed to the church itself. Before the bishop enters, the church is a type, Ivo states, of an ignorant people immersed in the darkness of faithlessness; they do not recognize the Petrine power bestowed by the Lord. But the bishop commands the demons and vices to open their doors. He enters the church and, prostrate on the floor, calls to God to sanctify the place. Associations between liturgy and dramaturgy are controversial, but it does seem that Ivo exploits the dramatic potential of the entry to the full.

Each ritual element is commented on and put in perspective by biblical references, some of which recur in readings and chants during the rite. After having zoomed in, as it were, on the church, Ivo employs the elements of the

94 Méhu, 'Historiae et imagines', 37.

95 'Quoniam ad dedicationem praesentis basilicae hodie devote convenistis, oportet ut quod in his sanctis manufactis fieri videtis, totum impletum esse in vobis cognoscatis.' Sermo 4, PL 162:527.

96 'Ista aqua ad quamdam baptismi imaginem gyrando ecclesiam tunc exterius aspergimus, quia ubi more baptizatorum non potest fieri trina mersio, necesse est ut qua possumus sacramenti similitudine trina fiat aspersio.' Sermo 4, PL 162:529. 
dedication ceremony to open the view towards a wider doctrinal horizon. The symbolism is dense and knotted. The diagonal writing of the alphabets is associated with the first rudimentary version of sacred doctrine which reaches Jews and Gentiles. The episcopal staff used for writing signifies the salvation reaching to the ends of the world through the sacerdotal office. ${ }^{97}$ The association of the alphabet with Jews and Gentiles is in tune with other interpretations, but it is in contrast to the 'Stave church sermon's' association of the people with the church walls. ${ }^{98}$ This reminds us that while motifs are relatively stable, their interpretations are not schematic. Doctrinal motifs are accumulated in Ivo's homiletic compendium: salt and ashes are mixed just as divine insight must merge with faith in the Passion; water mixed with wine signifies Christ's double nature, and the aspersion of the inner walls shows that exterior appearances must be complemented by interior saintliness. The sevenfold aspersion of the altar is done with water and hyssop. Hyssop is a humble, purging herb; it signifies Christ's humility which cured human pride when he aspersed it with his blood. The bishop wipes the altar with linen; linen comes from the earth and is bleached with much labour: this is Christ's flesh emerging from earth, signifying the Virgin, and he who reached resurrection through suffering. ${ }^{99}$

After a rich and dense explanation the bishop reaches his anagogical conclusion with Psalm 29:12: 'You have turned for me my mourning into joy'. This makes for a dialectical juxtaposition of the mournful present life and the vision of peace. Lamentation, Ivo states, will be turned to joy when we are brought through to the fatherland from which we are now exiled. The feast establishes a link to this eternal joy: it is the delightful and festive dedication of God's man-made temple in its wedding clothes, and he will preserve this temple until the eternal dedication. ${ }^{100}$

Ivo of Chartres exploits the stock repertory of dedication themes: the community as living stones, the universal Church and each baptized member of it, the completion of the dedication in beatitude. But their exact form and organization are shaped by his preoccupation with episcopal power and his intent to make the audience see the dedication of this new church in relation to their baptism. This intent he shares, to some extent, with the Stave church preacher, but whereas the Old Norse text centres on life cycles and guidelines for behaviour, Ivo's focus rests on the divine purging imparted in the sacrament and mediated by the bishop; he addresses the sacramental and salvational coherence

97 Sermo 4, PL 162:530-31.

98 Whose interpretation in turn equals Hugh of Saint-Victor's De sacramentis II.5.1, PL 176:439.

99 Sermo 4, PL 162:534.

100 Sermo 4, PL 162:535. 
between the Bible, the building and the doctrine, between the baptized and their church. We can only begin to surmise that these may have been issues that the audience was querying too.

\section{Bernard of Clairvaux: In dedicatione ecclesiae, sermo 1}

The Cistercian Bernard of Clairvaux (1090-1153) was a crusade preacher, church politician and prolific author. In his six sermons In dedicatione ecclesiae, completed after 1150, he writes, above all, as abbot. The commemoration of the dedication is one of the feasts for which the Cistercian manual Ecclesiastica officia prescribes that a sermon be delivered in the chapter, preferably by the abbot. ${ }^{101}$ The audience was the Cistercian community at its most comprehensive, including lay brothers, guests and familiares. ${ }^{102}$ Kienzle suggests that this retinue may have entailed straightforward, vernacular preaching. ${ }^{103}$ But in the written version Bernard's dedication sermons are literary compositions which presumably circulated among audiences beyond Clairvaux. ${ }^{104}$ Meyer considers the sermons to be a liturgical commentary on the rite. ${ }^{105}$ But again it seems well-advised to maintain a distinction between sermon and commentary. The texts retain an association with the idea of the abbot preaching to a monastic community; for instance, Bernard appears to survey his audience, observing 'so many youngsters, so many adolescents, so many noblemen'; ${ }^{106}$ elsewhere he speaks of the mood in which the audience will leave having heard the sermon. ${ }^{107}$ At the same time Bernard's dedication sermons form a coherent literary unit

101 Ecclesiastica officia 67.5, Les 'Ecclesiastica officia' cisterciens du XIIème siècle, ed. D. Choisselet and P. Vernet (Reiningue: Abbaye d'Oelenberg, 1989), 190; Chrysogonus Waddell, 'The Liturgical Dimension of Twelfth-Century Cistercian Preaching', in Medieval Monastic Preaching, ed. C. Muessig (Leiden: Brill, 1998), 335-49, at 336-39.

102 Chrysogonus Waddell, 'The Early Cistercian Experience of Liturgy', in Rule and Life: An Interdisciplinary Symposium, edited by M.B. Pennington (Spencer, MA: Cistercian Publications, 1971), 77-116 at 112nn107-8; Cistercian Lay Brothers: Twelfth-Century Usages with Related Texts ed. Chrysogonus Waddell (Cîteaux: Commentarii Cistercienses, 2000), 184, nn 2-4.

103 B.M. Kienzle, 'The Twelfth-Century Monastic Sermon', in The Sermon, ed. Kienzle, 271-323, at 279n41; M.B. Bruun, 'Mapping the Monastery: Hélinand of Froidmont's Second Sermon for Palm Sunday', in Prédication et liturgie au moyen âge, ed. Bériou and Morenzoni, 183-99, at 187-90.

104 Méhu, 'Historiae et imagines', 35.

105 Meyer, Medieval Allegory, 91.

106 '... tot iuvenes, tot adolescents, tot nobiles ..., In ded., sermo 1.2, Bernhard, ed. Winkler, 8: 812; Sancti Bernardi opera, ed. Leclercq, 5: 371.

107 In ded., sermo 5.2: Bernhard, ed. Winkler, 8: 848; Sancti Bernardi opera, ed. Leclerq, 5: 389 . 
with conscious development of motifs and escalating density. ${ }^{108}$ They are permeated by the allegorical dynamic and carefully crafted rhetoric typical of the abbot and thereby linked to the remainder of Bernard's work as much as to other dedication texts. ${ }^{109}$

Like Ivo of Chartres and the Stave church preacher Bernard begins by approaching his audience, but the abbot addresses a 'we' that is considered as a group apart from the Church at large: 'Today's feast, brothers, must for us be so much more worthy of devotion, as it is more related to us. For we have the other saints' feast in common with the other churches, but this one is our own since it is celebrated by no one but us. ${ }^{110}$ Then the abbot introduces one of his main themes: the relation between the building, each monk's body, and the soul which God beatifies on earth and sanctifies in heaven. ${ }^{111}$ Bernard rehearses the motif of the individual believer as the Lord's temple, but he dwells upon the corporeal aspect, speaking about the wonder which takes place when men decide to estrange themselves from gluttony, drunkenness and lasciviousness for the rest of their lives. He speaks in the language of Exodus about their individual paths: each knows the wonder that brought him to leave Egypt and traverse the desert of renunciation. The perspective is exclusively monastic.

The monks' conversion stories prove that the Holy Spirit inhabits their bodies. They have been dedicated to the Lord; not only those who were present at the consecration, but 'anybody who does service for God in this place to the end of time. ${ }^{112}$ With this prelude the abbot reaches his Christological peak:

108 On the relation between oral markers and literary style see the positions of Jean Leclercq, 'Les sermons sur les cantiques ont-ils été prononcés?, in Recueil d'études sur $S$. Bernard et ses écrits, 3 vols. (Rome: Storia et Letteratura, 1962), 2: 193-212, esp. 199-200, summarized in his introduction to Bernard of Clairvaux: Sermons on the Song of Songs II, trans. K. Walsh (Kalamazoo, MI: Cistercian Publications, 1983), vii-xxx; Christopher Holdsworth, 'Were the Sermons of Bernard on the Song of Songs ever Preached?', in Medieval Monastic Preaching, ed. Meussig, 295-318, esp. 308-11; and Wim Verbaal, 'Réalités quotidiennes et fiction littéraire dans les Sermons sur le Cantique de Bernard de Clairvaux', Cîteaux 51 (2000): 201-18.

109 This is against Horie's view that Bernard 'allows his thoughts to flow freely'; Horie, Perceptions of Ecclesia, 31.

110 'Festivitas hodierna, fratres, tanto nobis debet esse devotior, quanto familiarior est. Nam ceteras quidem Sanctorum sollemnitates cum ecclesiis aliis habemus communes; haec vero sic nobis est propria, ut necesse sit, vel a nobis eam, vel a nemine celebrari. Nostra est, quia de ecclesia nostra, magis autem nostra est, quia de nobis ipsis.' In ded., sermo 1.1: Bernhard, ed. Winkler, 8:811 (Sancti Bernardi opera, ed. Leclerq, 5:370).

111 In ded., sermo 1.1: Bernhard, ed. Winkler, 8:810 (Sancti Bernardi opera, ed. Leclerq, 5:369); see also Harris, 'Body as Temple', 248-49.

112 '... quicumque usque in finem saeculi Domino sunt in hoc loco militaturi.' In ded., sermo 1.3: Bernhard, ed. Winkler, 8:814 (Sancti Bernardi opera, ed. Leclerq, 5:372). The second Clairvaux was built in 1135 and some members of the audience may have 
'Thus in us must be carried out spiritually what earlier happened visibly on the walls. And that, if you want to know, is aspersion, inscription, unction, illumination and benediction. This have the bishops carried out visibly in this house; this Christ [...] carries out invisibly in us each day.' ${ }^{\prime 13}$ We recognize the association of the ritual action and the interior work of grace from Ivo's sermon, but instead of speaking of the work of grace in association with baptism, the abbot describes it as an ongoing process. Bernard elaborates each element: the purging is brought about by the hyssop of humility, the aspersion by the tears of confession and the water from Christ's side wound, the source of love. For both Ivo and Bernard hyssop signifies humility. But while Ivo associated the herb with Christ, Bernard links it to the humility demanded of monks. Bernard's notion of humility is related to Christ's example but has its particular place in the monastic mindset, revolving around the Rule of Benedict's twelve steps of humility. The diagonal alphabets signify the law written not in stone, but in hearts, with God's exorcizing finger. Once again we see that motifs resonate, but in other tonalities.

Across the next five sermons Bernard traces a grand loop, intertwining the threads of the three spiritual modes of interpretation. He moves via the soul as God's lodging, a soldier's tent (sermo 2) and a walled camp attacked by enemies (sermo 3), to the ascent to the peace of beatitude (sermo 4) and the recognition of the darkness of sin and the light of hope (sermo 5) before he brings his elaboration to a safe landing in the present:

For us this dedication of our house is a family celebration, even more familial, however, is the dedication of ourselves. Ours was that aspersion, ours that benediction and ours that consecration, which was carried out by the holy hands of the bishop, and which, with the anniversary recurring today, is called to memory through solemn praises. ${ }^{114}$

remembered its dedication; Thomas Coomans, 'Cistercian Architecture or Architecture of the Cistercians?', in The Cambridge Companion to the Cistercian Order, ed. Mette Birkedal Bruun (Cambridge: Cambridge University Press, 2012), 151-69, at 157.

113 'In nobis proinde spiritualiter impleri necesse est, quae in parietibus visibiliter praecesserunt. Et si vultis scire, haec utique sunt: aspersio, inscriptio, inunctio, illuminatio, benedictio. Haec quidem in hac visibili domo fecere pontifices; haec Christus [...] invisibiliter quotidie operatur in nobis.' In ded., sermo 1.4: Bernhard, ed. Winkler, 8:814 (Sancti Bernardi opera, ed. Leclerq, 5:372).

114 'Domestica nobis celebritas dedicatio domus nostrae, magis autem domestica nostra ipsorum dedicatio est. Nostra siquidem illa aspersio, nostra illa benedictio, nostra consecratio fuit, quae per manus sanctorum celebrata Pontificum, etiam hodie anniversario reditu votivis laudibus ad memoriam revocatur.' In ded., sermo 6.1: Bernhard, ed. Winkler, 8:862 (Sancti Bernardi opera, ed. Leclerq, 5:396). 
Bernard takes his point of departure from the material world. References to the building recur throughout, but he also lingers over each monk's individual combat with vice. His is a metaphorical construction: what the bishop does in the dedication resembles Christ's actions in the soul. In order for the metaphor to function, one part must make immediate sense; the dedication must connote an event at which things are done to the building. ${ }^{115}$ The association between the building and the soul is not unique to Bernard. ${ }^{116}$ However, in his portrayal of the things done to the building and to the soul Bernard evokes his basic interpretative principle: the development from an understanding in carne (according to the flesh) to an understanding in spiritu (according to the spirit). ${ }^{117}$ Envisioning the dedication will help his audience understand the ineffable workings of Christ in their own souls. From this basis the abbot proceeds into a dense elaboration of typically Bernardine themes. The dedication is the point of departure, but it seems that, for author and audience, the real interest rests less with the interpretation of the dedication than with the dedication as a cognitive tool for the understanding of how Christ works in each monk as he proceeds towards beatitude. We recognize key dedication motifs, but the tone is distinctly Bernardine.

\section{Conclusions}

What did the dedication signify to medieval people? Which texts are we to turn to if we want to find out? A reading across commentaries and sermons shows dominant motifs. But if we want to gain the slightest idea - and slight it is - of the audience's understanding, one way is to turn to specific texts and the queries they address. In this respect, sermons are arguably more suggestive than commentaries, owing to their communicative obligation to a specific audience. No matter how literary or how theoretical, sermons speak to a particular

115 Hamilton suggests a similar interpretation for Bruno of Segni's comparison of the crowds gathering for dedication to the crowds in Noah's ark: the comparison only works if crowds did in fact gather; Sacred City, 61.

116 It echoes Augustine's 'Quod hic factum corporaliter videmus in parietibus, spiritualiter fiat in mentibus', Sermo 336, PL 38:1475, and reappears in Hugh of SaintVictor's De sacramentis II.5.1, PL 176:439.

117 For example Super cantica canticorum, sermo 6.3: Bernhard, ed. Winkler, 5:102 (Sancti Bernardi opera, ed. Leclerq, 1:27); In Adventu, sermo 1.10: Bernhard, ed. Winkler, 7:72-73 (Sancti Bernardi opera, ed. Leclerq, 4:168-69); Denis Farkasfalvy, 'Use and Interpretation of St John's Prologue in the Writings of Saint Bernard', Analecta cisterciensia 35 (1979): 205-66; M.B. Pranger, Bernard of Clairvaux and the Shape of Monastic Thought: Broken Dreams (Leiden: Brill, 1994); M.B. Bruun, Parables: Bernard of Clairvaux's Mapping of Spiritual Topography (Leiden: Brill, 2007), 37-39 and 283-85. 
interpretative community. The contours of such communities, however vague, begin to appear when we examine the ways in which particular authors shaped stock motifs and made them relevant in a given context - even when this was not done as explicitly as in Bernard of Clairvaux's 'Ours was that aspersion, ours that benediction, ours that consecration ....

The dedication consecrates the church as a place that is holy and in which one encounters the holy. Interpretations of the rite reflect on the life and faith framed by the building. These interpretations are often rooted in the four-fold method of interpreting scripture. They tend to be all-inclusive, comprehending, albeit rudimentarily, ecclesiology, Christology and eschatology as well as the belief and conduct of the community and its individual members. Interpretations tend to reproduce an overarching set of motifs, even as diversity abounds. Genre is key. Therefore dedication commentaries and sermons must be considered not only within the semantic universe established by the rite, but also within their individual conceptual worlds, emerging against the backdrop of generic conventions, communities of interpretation and authorial perspectives.

\section{Reflections}

If ritual matters to history, then differences and nuances in ritual also matter. The more generic our understanding of the ritual is, the more generic our conclusions about its import will be: in the example of the dedication rite, that it marked communal identity and power and conveyed particular typological structures. The more precise our understanding of the ritual employed, the more subtle our analysis of its significance can become. If we can analyse precise rituals and how they were practised and perceived, then we can, in turn, discern the interpretive communities that they address and the subcommunities of antipathy and amity that they establish. Ideally, we can see how ritual generates, not simply reflects, power. It is no surprise that bishops wished to mark themselves and their actions as politically and soteriologically powerful. What is more interesting, and more difficult, is to understand how these efforts were received as that tells us about both the resistance to, and the generation of, power.

New methods are needed to coordinate the multiple sources and varieties of evidence that enable multivocal readings of a liturgy and to trace the changing significances of a space and a practice over time. One promising area of development is the growing interest in the possibilities of geographic information systems (GIS) as a tool for historical analysis. GIS enables us to locate multiple forms of evidence (visual and textual) at a precise latitude and longitude. That permits the analysis of the historical evidence in its geographic context on a map. With such tools one can analyse how the larger built environment, either within a church, city or landscape, and the multiple levels of meaning it signified to contemporaries, helped shape 
the local significances of specific liturgical events. While modern historians have begun to exploit these tools, medievalists have yet to fully embrace them. ${ }^{118}$ The closest efforts so far by medievalists that we know of, is the work being done on medieval Chester. ${ }^{119}$

This method is particularly helpful to capture the allegorical approach to space as it enables the coordinated analysis of texts and objects within a landscape, what Mette Bruun has called, 'the textual representation of topography. ${ }^{120}$ Sermons for the dedication and its annual commemoration create a form of palimpsest. They map a spiritual topography onto the physical topography of the church and its surroundings, elaborating on the topographical allusions of the rite. This spiritual topography encompasses Old Testament locales such as Solomon's Temple and the terribilis locus where Jacob encountered God as well as the eternal heavenly homeland. We cannot know how this palimpsestic speech-act was conceived by the participants. The medieval allegorical climate was such that the association between a particular church and its specific political context and location on the one hand and the celestial beatitude on the other would not seem foreign. But individual perceptions must be surmised from reactions: be they the violent resistance

118 See Louis I. Hamilton, 'The Rituals of Renaissance: Liturgy and Mythic History in The Marvels of Rome', in Rome Re-Imagined: Twelfth-Century Jews, Christians, and Muslims Encounter the Eternal City, ed. Louis I. Hamilton and Stefano Riccioni (Leiden: Brill, 2012), 417-38; Hamilton, 'Virtual Cities: GIS as a Tool for the Analysis of Dante's Commedia', Pedagogy: Critical Approaches to Teaching Literature, Language, Composition, and Culture 13, no. 1 (2013): 115-24. While archaeologists have been earlier adaptors of GIS, the application of this tool to the analysis of texts and images by medievalists has been slow. See the proposed application of digital technologies to liturgical sources, including a mention of GIS possibilities, in James Cummings, 'Liturgy, Drama, and the Archive: Three Conversions from Legacy Formats to TEI XML', Digital Medievalist 1 (2006), at http://www. digitalmedievalist.org/journal/2.1/cummings/ at $\$ 41$ (accessed 1 March 2013). Textual representation of topography proposed is much broader than the digital study of medieval maps, per se; on the latter see the important work of Martin K. Foys and Shannon Bradshaw, 'Developing Digital Mappaemundi: An Agile Mode for Annotating Medieval Maps', Digital Medievalist 7 (2011), at www.digitalmedievalist.org/journal/7/foys/ (accessed 1 March 2013). On the field of historical GIS and its possibilities as explored by modern historians, see Jordi Martí-Henneberg, 'Geographical Information Systems and the Study of History', Journal of Interdisciplinary History 42 (2011): 1-13; David Cooper and Ian N. Gregory, 'Mapping the English Lake District: A Literary GIS', Transactions of the Institute of British Geographers 36 (2011): 89-108; Donald A. DeBats and Ian N. Gregory, 'Introduction to Historical GIS and the Study of Urban History', Social Science History 35 (2011): 455-63.

119 Catherine Clarke et al., 'Mapping Medieval Chester', at http://www.medievalchester. ac.uk/about/mappings.html (accessed 1 March 2013).

120 See Bruun, Parables, 19-24. 
against episcopal authority or the more peaceful responses anticipated or evoked by sermons.

The consecration of a church drew its possible meanings from a broad range of local and pan-European sources. When we work with the dedication rite, we must make an effort to coordinate those sources - and to do so with an acute consciousness of the range of information which may be gathered from each particular source. Only thus can we counter the risk of confusing one asserted meaning for the totality of its significances, or the significance imparted to any given viewer. 